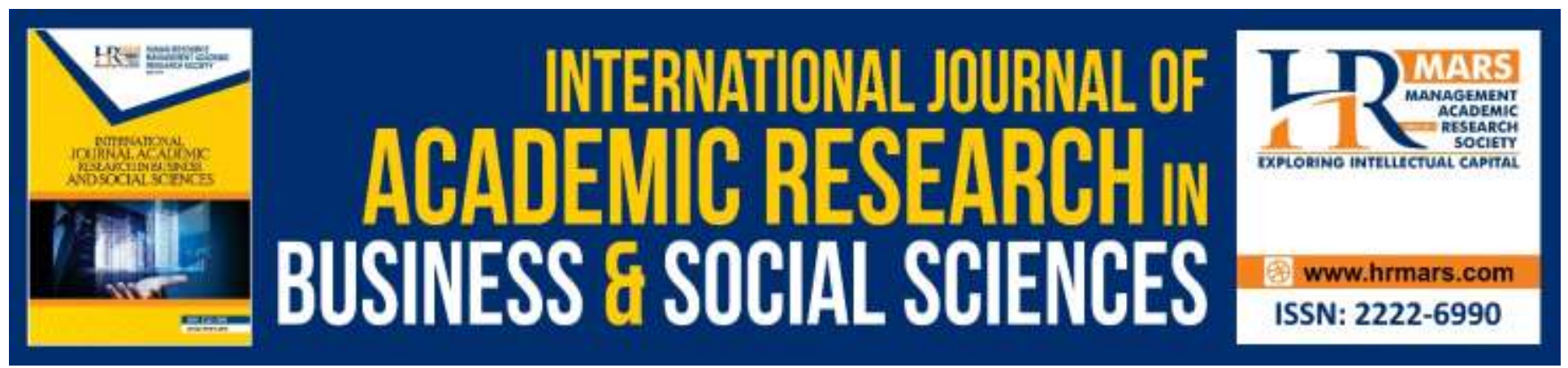

\title{
Fun Learning Approaches in Enhancing Patriotism Values among Preschool Children
}

Samni Suraji, Abdul Razaq Ahmad, Mohd Mahzan Awang, Nordin Mamat \& Ahmad Ali Seman

To Link this Article: http://dx.doi.org/10.6007/IJARBSS/v8-i8/4455

DOI: $10.6007 /$ IJARBSS/v8-i8/4455

Received: 24 June 2018, Revised: 29 July 2018, Accepted: 16 August 2018

Published Online: 31 August 2018

In-Text Citation: (Suraji, Ahmad, Awang, Mamat, \& Seman, 2018)

To Cite this Article: Suraji, S., Ahmad, A. R., Awang, M. M., Mamat, N., \& Seman, A. A. (2018). Fun Learning Approaches in Enhancing Patriotism Values among Preschool Children. International Journal of Academic Research in Business and Social Sciences, 8(8), 149-155.

Copyright: (C) 2018 The Author(s)

Published by Human Resource Management Academic Research Society (www.hrmars.com)

This article is published under the Creative Commons Attribution (CC BY 4.0) license. Anyone may reproduce, distribute, translate and create derivative works of this article (for both commercial and non-commercial purposes), subject to full attribution to the original publication and authors. The full terms of this license may be seen

at: http://creativecommons.org/licences/by/4.0/legalcode

Vol. 8, No. 8, August 2018, Pg. 149 - 155

Full Terms \& Conditions of access and use can be found at http://hrmars.com/index.php/pages/detail/publication-ethics 


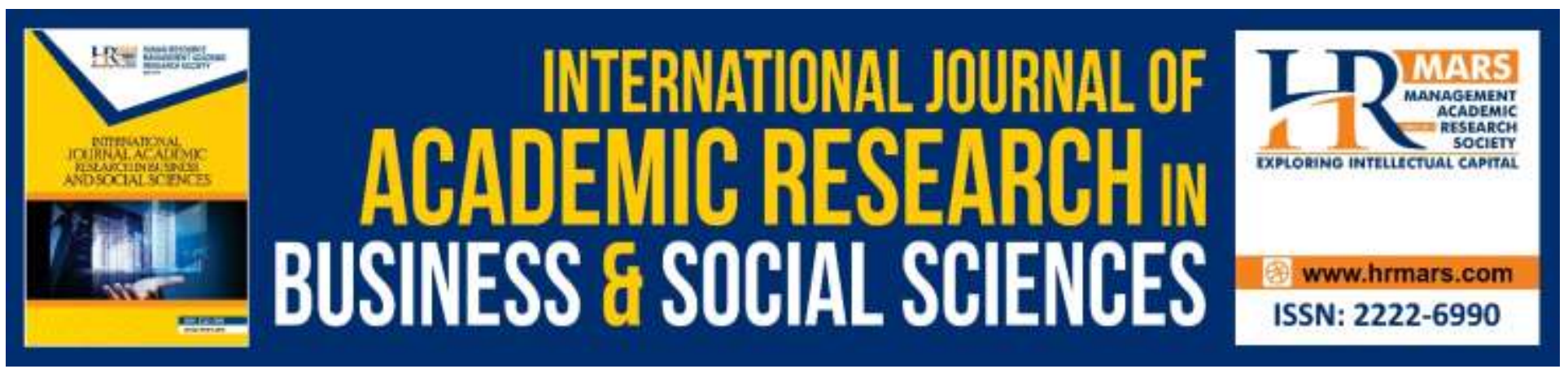

\title{
Fun Learning Approaches in Enhancing Patriotism Values among Preschool Children
}

\author{
Samni Suraji ${ }^{1}$, Abdul Razaq Ahmad², Mohd Mahzan Awang ${ }^{3}$, Nordin \\ Mamat ${ }^{4} \&$ Ahmad Ali Seman ${ }^{5}$ \\ $1,2 \& 3$ Faculty of Education, The National University of Malaysia, ${ }^{4}$ Sultan Idris Education University, \\ ${ }^{5}$ Faculty of Social Sciences and Humanities, The National University of Malaysia
}

\begin{abstract}
This quasi experiment study aims to identify the effectiveness of Fun Learning module in enhancing patriotism among preschool children. This quasi experiment involved 1000 sample from 4 preschools under government. Treatment group involved 50 pupils from 2 classes in 2 preschools as well as controlled group. The preschools were randomly selected in Kuching District, Sarawak, Malaysia. Fun Learning in this study comprises of 15 main modules conducted in 12 weeks whereas patriotism is related to knowledge and love to the country. Results from pilot study based on Cronbach's Alpha analysis revealed that all items in the whole constructs were at high reliability level between 0.82 and 0.91. data were analysed using SPSS 22.0 involving descriptive and inferential analyses. Findings show that there are significant differences between treatment and controlled groups in which treatment group show high min differences for all aspects related to knowledge and patriotism. Implications of the study demonstrate that fun learning approaches are suitable for cognitive level and preschool children's interest in improving historical values via history learning at early childhood stage.
\end{abstract}

\section{Introduction}

History education is vital in shaping patriotism values and to further shape national identity (Khoo, 1992). Other than that, it also performs as a central for instilling patriotism values and national character among multi-ethnic society particularly in Malaysia. This is due to factual information on past events being provided in the curriculum as well as detailed lessons on nation-building process. In Malaysian context, history education has undergone several changes where since 2010 it has been acknowledged as compulsory subject to pass in Malaysian Certificate of Education (SPM) for secondary school students. This effort implies the significance of history subject in Malaysian education system.

In 2014, history subject is integrated in the primary school curriculum which the main aims are to promote a high appreciation of patriotism value since early age and to nurture their spirit and love for the nation. Meanwhile, in the following two years, a reformation has been made by 
INTERNATIONAL JOURNAL OF ACADEMIC RESEARCH IN BUSINESS AND SOCIAL SCIENCES

Vol. 8, No. 8, August 2018, E-ISSN: 2222-6990 @ 2018 HRMARS

introducing history subject at preschool level. This is performed by Ministry of Education (2016) under the humanities pillar as a way for a more underpinning history background for the children.

\section{Literature Review}

The term "early education" refers to education for children from birth to age six which is funded and delivered by several government agencies and non-governmental organizations (NGOs), but is not part of the formal education system and not compulsory (Ministry of Education, 2005). According to Philosophy of Education in Malaysia, every child has the right for equal opportunities in education despite their economic and social backgrounds. Early childhood education performs as a training platform for the children and preparing them before entering the next education level (Tomporowski, Lambourne \& Okumura, 2011). Hence, considering the children's cognitive abilities in learning, teaching history is quite different to teaching other subjects. It involves series of significant events in the world that occurred before our eyes thus making it more challenging for the teachers to deliver the contents effectively in the classroom. To tackle this situation, variety of teaching aids and methods can be applied during history teaching and learning process (Ahmad \& Awang, 2016). One of it is through fun learning approach in which children learn to have fun while picking on some important historical aspects. Fun learning in this study consists of casual learning, playing, the use of teaching aids and music, hands on activities, informal learning, social interaction among friends, inquiry, treasure hunt and various students-centered activities.

Many scholars have addressed the benefits of fun learning at early stage given that children have short attention span thus easily lost focus during classroom activities (Mura et.al, 2015; Rasberry, Lee \& Robin, 2011). Children's participation in classroom activities is highly influenced by their teachers' guidance and directions. Therefore, fun approaches may facilitate children's learning particularly in history subject and making it easier for them to absorb the content as they are getting engaged with the environment. History teachers can take advantages of this method to improve pupils' performances and achievements in learning the subject. Aspects of patriotism can be implemented effectively during the activities conducted.

\section{Aim of the Study}

This current study aims to identify the effectiveness of Fun Learning module in enhancing patriotism among preschool children. Fun learning module refers to casual learning, playing, the use of teaching aids and music, hands on activities, informal learning, social interaction among friends, inquiry, treasure hunt and various students-centered activities. Meanwhile, patriotism is related to knowledge and love for the country.

\section{Methodology}

This quasi experimental study involved pre-test and post-test analysis. The sample for this study consisted of 100 pupils which were randomly selected from 4 preschools in Kuching district located in Sarawak, Malaysia. The sample was distributed into two groups namely treatment and controlled which consists of 50 pupils from 2 classes in 2 preschools respectively. A set of questionnaire was employed to collect the data from the respective respondents. The questionnaire was adapted from past studies including Ismail (2012), Ali (2017), Seman (2011) and Ayudin (2011). All of the questionnaires aimed at measuring the historical knowledge and empathy values inclusive of patriotism and citizenship values for secondary school level. In this study, the items in the 
INTERNATIONAL JOURNAL OF ACADEMIC RESEARCH IN BUSINESS AND SOCIAL SCIENCES

Vol. 8, No. 8, August 2018, E-ISSN: 2222-6990 @ 2018 HRMARS

questionnaire were amended and simplified to suit preschool pupils' cognitive abilities and historical knowledge. Prior to data collection, a pilot study was conducted to validate the questionnaire used for treatment and controlled groups. Results from pilot study showed that all items in the whole constructs have high reliability level between 0.82 and 0.91 . Following the result, the questionnaire is valid to be used for real data collection.

\section{Findings}

Table 1 T-test analysis

\begin{tabular}{ccccccc}
\hline Patriotism & Group & N & Mean & $\begin{array}{c}\text { Standard } \\
\text { Deviation }\end{array}$ & t & Sig \\
\hline Pre-test & Controlle & & & & 0.025 & 0.493 \\
& $\begin{array}{c}\mathrm{d} \\
\end{array}$ & & & & & \\
& $\begin{array}{c}\text { Treatme } \\
\text { Post-test }\end{array}$ & 50 & 2.86 & 0.24 & & \\
& Cont & 50 & 2.90 & 0.20 & & \\
\hline & d & & & & 1.145 & 0.011 \\
& Treatme & 50 & 2.41 & 0.20 & & \\
& nt & 50 & 2.63 & 0.54 & & \\
\hline
\end{tabular}

\section{Level of Patriotism among Preschool Children}

Descriptive analysis which involves mean and standard deviation was conducted to identify the level of patriotism among preschool children for the treatment groups. The results of the analysis are as follows:

Table $2 \mathrm{~T}$ test analysis on patriotism construct differences before and after using Fun Learning approach

\begin{tabular}{lccrrrrr}
\hline Value & Differences & $\mathrm{N}$ & Mean & $\begin{array}{r}\text { Standard } \\
\text { Deviation }\end{array}$ & $\mathrm{T}$ & $\mathrm{df}$ & Sig. \\
& Before & 100 & 3.04 & 0.573 & -18.951 & 109 & 0.000 \\
\hline Patriotism & After & 100 & 4.27 & 0.340 & & \\
& & & & & &
\end{tabular}

Based on table 2 above, it shows that there is an improvement for the aspect of patriotism level among preschool pupils in treatment groups. The post test revealed that treatment groups that implement Fun Learning approach in the classrooms have higher mean score value (mean= 3.04) as compared to previous standard teaching and learning skills (3.04). This clearly shows that learning in a more fun way may enhance pupils' achievement as they interact and engage more in the classroom setting (Bi, 2013; Zirawaga, Olusanya \& Maduku, 2017). 
INTERNATIONAL JOURNAL OF ACADEMIC RESEARCH IN BUSINESS AND SOCIAL SCIENCES

Vol. 8, No. 8, August 2018, E-ISSN: 2222-6990 @ 2018 HRMARS

Table 3 Level of Empathy Values for Patriotism Aspect Among Preschool Children in Treatment Groups Based on Pre and Post Tests

\begin{tabular}{|c|c|c|c|c|c|c|c|}
\hline \multirow[t]{3}{*}{ No } & \multirow[t]{3}{*}{ Statement } & \multicolumn{3}{|c|}{ Before } & \multicolumn{3}{|c|}{ After } \\
\hline & & Mean & Standard & Interpretati & Mea & Standard & Interpretati \\
\hline & & & Deviation & on & $\mathrm{n}$ & $\begin{array}{c}\text { Deviatio } \\
\mathrm{n}\end{array}$ & on \\
\hline \multirow[t]{2}{*}{1} & Love for the state & 2.09 & 0.67 & Moderatel & & & \\
\hline & $\begin{array}{l}\text { and country's } \\
\text { leaders }\end{array}$ & & & $y$-Low & 4.37 & 0.81 & High \\
\hline 2 & $\begin{array}{l}\text { Proud of nation's } \\
\text { leaders' battle }\end{array}$ & 1.87 & 0.76 & $\begin{array}{c}\text { Moderatel } \\
\text { y-Low }\end{array}$ & 4.50 & 0.50 & High \\
\hline \multirow[t]{2}{*}{3} & Prod to be & 2.03 & 0.89 & Moderatel & & & \\
\hline & Malaysian & & & y-Low & 4.50 & 0.50 & HIgh \\
\hline \multirow[t]{2}{*}{4} & Take care of & 2.02 & 0.63 & Moderatel & & & \\
\hline & $\begin{array}{l}\text { Malaysia and } \\
\text { states flags }\end{array}$ & & & $y$-Low & 4.61 & 0.49 & High \\
\hline \multirow[t]{2}{*}{5} & Appreciate past & 1.45 & 0.79 & Low & & & Moderately \\
\hline & historical heritage & & & & 4.01 & 0.82 & -Low \\
\hline \multirow[t]{2}{*}{6} & Prefer to speak & 2.00 & 0.98 & Moderatel & & & \\
\hline & $\begin{array}{l}\text { using national } \\
\text { language }\end{array}$ & & & $y$-Low & 4.62 & 0.48 & High \\
\hline \multirow[t]{2}{*}{7} & Engage with multi- & 2.40 & 0.85 & Moderatel & 416 & 083 & Moderately \\
\hline & ethnic friends & & & y-Low & & 0.05 & -High \\
\hline \multirow[t]{2}{*}{8} & Love for the King & 1.90 & 0.95 & Low & & & \\
\hline & $\begin{array}{l}\text { as leader of the } \\
\text { nation }\end{array}$ & & & & 4.50 & 0.50 & High \\
\hline \multicolumn{2}{|c|}{ Overall Mean } & 1.97 & 0.81 & $\begin{array}{c}\text { Moderatel } \\
\text { y-Low }\end{array}$ & 4.40 & 0.61 & Tinggi \\
\hline
\end{tabular}

Deskriptive analysis in table 3 above shows that the overall level for patriosme in treatment group is only at moderately-low for pre test with mean score (1.97). Empathy values related to appreciate past historical heritage (mean=1.45) and love for the King as leader of the nation (mean=1.90) are only at low level. Meanwhile, for other aspects such as love for the sate and country's leaders (mean=2.09), engage with multi-ethnic friends (mean=2.40), proud to be Malaysian (mean=2.03), take care of Malaysia and state flags (mean=2.02), prefer to speak using national language (mean=2.00) and proud of nation's leaders' battle (mean=1.87) are at moderately-low level.

For post test, the overall level for the treatment group shows improvement with mean score =4.40. Empathy values on speaking using national language has the highest mean score (mean=4.62) and followed by taking care of Malaysia and state flags (mean=4.61). Meanwhile, empathy values regarding on proud of nation's laeders' battle, proud to be Malaysian and love for the King as leader of the nation have similar mean score (mean=4.50). It is then followed by love for the leaders of nation and states (mean=4.37), engage with multi-ethnic friends (mean=4.16) and appreciate past historical heritage (mean=4.01). 
INTERNATIONAL JOURNAL OF ACADEMIC RESEARCH IN BUSINESS AND SOCIAL SCIENCES

Vol. 8, No. 8, August 2018, E-ISSN: 2222-6990 @ 2018 HRMARS

\section{Discussions}

Based on the findings, it is proven that by exploring history subject through a fun and interactive method may foster pupils' understanding and knowledge about history more effectively. Memorable learning through fun activities may promote children's interest in learning history and allows them to be more attentive and eager to learn about the history of their families, friends, schools and country (Aziz \& Ismail, 2007). This finding is also in line with Ahmad \& Jinggan (2015) which stated that learning history begins with exploring the story of oneself including the family, community and local history. Another study by Yue \& Zin (2009) revealed that game-based approach in learning history is one of the effective ways to increase pupils' participation in classroom activities. Learning history is not only about memorising dates or facts. It is acquiring the necessary skills and thought processes needed to respond appropriately under challenging situations. The children are being fed information when they should be developing their own understandings in history to build up their knowledge. Preschools administrators and teachers should help prepare the children through effective and interactive experiences that will motivate them and actively engage them in the history learning process. Learning while having fun may develop a meaningful sense of what one's experience is all about and nurture understanding on the context itself.

\section{Implications and Suggestions}

The use of Fun Learning approach can facilitate teachers in handling the children's favorable learning process. This approach is more student-centered as compared to the standard teaching method which highly focused on teacher-centered. Teachers should prepare the teaching material needed to create fun learning environment as to promote casual learning, game-based inquirí, hands on activities, informal learning and various of student-centered activities. This module plays vital role in fostering children's engagement in history classroom as well as making it more easier for them to understand basic historical contents and to apreciate the values of history in their life. This approach is not only limited in teaching history but also can be implemented in other subjects as well.

\section{Conclusion}

The current study has proven that the use of Fun Learning approach may Foster pupils' interest and achievement in history subject particularly in improving their patriotism values and sense of belonging for the nation. Hence, teachers and school administrator should take into account as to enhance the curriculum and pedagogical context in history subject. This approach can also be applied in other subjects as it meets pupils' necessity for early chilhood learning. Based on the above findings and discussions, this study provide additional insights on the benefits of learning through fun and interactive approaches particularly in history subject towards enhancing children's knowledge and interest from early stage of age.

\section{References}

Ahmad, A. R., \& Awang, M. M. (2016). Kurikulum Standard Sekolah Rendah (KSSR) Mata Pelajaran Sejarah: Perlaksanaan dan Cabaran. Proceeding 7th International Seminar on Regional Education. 435-445.

Ayudin, A. R. (2011). Penilaian keberkesanan pengajaran sejarah terhadap pencapaian matlamat pembelajaran, kesediaan belajar, kefahaman konsep dan pemikiran sejarah. Universiti Kebangsaan Malaysia. 
INTERNATIONAL JOURNAL OF ACADEMIC RESEARCH IN BUSINESS AND SOCIAL SCIENCES

Vol. 8, No. 8, August 2018, E-ISSN: 2222-6990 @ 2018 HRMARS

Aziz, Z., \& Ismail, N. A. N. (2007). Kajian tinjauan kesediaan guru -guru sejarah menerapkan kemahiran pemikiran sejarah kepada para pelajar. Jurnal Pendidikan. 32: 119-137.

$\mathrm{Bi}, \mathrm{T}$. (2013). Making full use of education games' role in promoting learning. International Conference on Information Technology and Applications. 172-175. http://dx.doi.org/10.1109/ita.2013.46

Ismail, A. (2012). Kesan model STAD terhadap patriotisme. sikap dan kemahiran komunikasi pelajar terhadap mata pelajaran sejarah. tesis doktor falsafah. Universiti Kebangsaan Malaysia. Bangi

Ma, K., Mare, L. L., \& Gurd, B. J. (2015). Four minutes of in-class high-intensity interval activity improves selective attention in 9- to 11-year olds. Applied Physiology, Nutrition, and Metabolism. 40(3). 238-244.

Mura, G., Vellante, M., Nardi, A. E., Machado, S., \& Carta, M. G. (2015). Effects of school-based physical activity interventions on cognition and academic achievement: A systematic review. CNS and Neurological Disorders - Drug Targets. 14(9). 1194-1208.

Rasberry, C. N., Lee, S. M., \& Robin, L. (2011). The association between school-based physical activity, including physical education, and academic performance: A systematic review of the literature. Preventive Medicine, vol. 52. S10-S20.

Seman, A. A. (2011). Pembelajaran sejarah berteraskan perspektif kepelbagaian budaya terhadap pembentukan integrasi nasional. tesis dokor falsafah. belum diterbitkan. Universiti Kebangsaan Malaysia.

Tomporowski, P. D., Lambourne, K., \& Okumura, M. S. (2011). Physical activity interventions and children's mental function: an introduction and overview. Preventive Medicine, vol. 52, S3S9.

Yue, W., \& Zin, N. (2009). History educational games design. Institute of Electrical and Electronics Engineers (IEEE).

Zirawaga, V. S., Olusanya, A. I., \& Maduku, T. (2017). Gaming in education: using games as a support tool to teach history. Journal of Education and Practice. ISSN 2222-1735 (Paper). 8(15). 